\title{
Recognizing Landscapes for the Purpose of Sustainable Development-Experiences from Poland
}

\author{
Iga Solecka ${ }^{1, *(\mathbb{D}}$, Dietmar Bothmer ${ }^{2}$ and Arkadiusz Głogowski ${ }^{3}$ \\ 1 Department of Spatial Economy, The Faculty of Environmental Engineering and Geodesy, \\ Wrocław University of Environmental and Life Sciences, ul. Grunwaldzka 55, 50-357 Wrocław, Poland \\ 2 Department of Natural and Environmental Sciences, Institute of Ecology and Environmental Protection, \\ University of Applied Sciences Zittau/Goerlitz, Theodor-Körner-Allee 16, 02763 Zittau, Germany; \\ d.bothmer@hszg.de \\ 3 Institute of Environmental Protection and Development, The Faculty of Environmental Engineering and \\ Geodesy, Wrocław University of Environmental and Life Sciences, pl. Grunwaldzki 24, 50-363 Wrocław, \\ Poland; arkadiusz.glogowski@upwr.edu.pl \\ * Correspondence: iga.solecka@upwr.edu.pl
}

Received: 17 April 2019; Accepted: 12 June 2019; Published: 21 June 2019

\begin{abstract}
Landscape identification forms a base for landscape management and sustainable land use policy. According to the European Landscape Convention, each Member State needs to recognize the landscapes as an essential component of people's surroundings. Poland developed a method for landscape auditing that will be conducted for landscapes in the whole country. The identification of landscape units is based on landscape type characteristics and spatial data that is layered and analyzed in order to identify landscape units. In this paper, we aim to test the possibilities of automatic landscape identification. We take the assumptions designed for landscape identification for the needs of the audit. Based on the "Typology of Poland's current landscapes", we design a process to identify landscape units with the use of the aggregation of land cover data and multivariable analysis. We use tools in an ArcGIS environment to design a process that will support human perception. Our approach is compared with the approach presented in the method designed for a landscape audit in order to be used for landscape unit identification at the municipal level. The case study area is the municipality of Siechnice within the suburban area of the city of Wrocław, an example of a changing landscape under suburbanization pressure. We conclude that both approaches can support each other in the landscape identification process.
\end{abstract}

Keywords: landscape unit; landscape identification; landscape management; GIS tools; European Landscape Convention; suburban area; suburbanization pressure; landscape audit

\section{Introduction}

The idea of recognizing landscapes was born before the European Landscape Convention (ELC). The concept of a landscape unit ("land unit") as the basic landscape system was explained by Zonneveld [1]. A land unit is a homogenous tract of land in terms of climate, terrain (geomorphology and soils), and vegetation, according to the associated scale. This approach was used widely in landscape ecology [2,3] and planning [4,5]. The use of this concept in a landscape character assessment in different European countries was widely described by Wascher [6]. One of the first was landscape delimitation in Estonia by Granö [7]. He identified 22 districts based on homogeneous regions identified by cartographic methods with the use of orthographical, hydrographical, administrative, and anthropo-geographical borderlines that covered the entire country. After adopting ELC [8], a lot of attention was drawn to recognizing landscapes. One of the typologies designed after 2000 was the 
Czech typology of landscapes based on natural features, socioeconomic conditions, and cultural objects and was developed by Low et al. in 2005 [9]. The landscape in Slovakia was illustrated by the map based on identifying complex, synthetic natural landscape units and with an emphasis on possible natural vegetation, called potential geosystems [10]. Other examples are the Natural Character Areas developed for England based on wildlife, natural features, and land use distributions, which consist of a set of 159 profiles [11]. Different typologies consider particular landscape elements (cultural and natural) and serve different purposes. Pioneering work dividing Poland into physicogeographical macro and meso regions by Kondracki [12] was used in landscape research. His work, characterized by a geographical approach, became a base for further landscape assessment. One of them was the architectural-landscape units by Bogdanowski [13], who analyzed cultural landscapes based on landform and land cover for the whole country.

\subsection{Historical Context of Polish Landscape Character}

Palang et al. [14] outlined that there was a difference between the way the landscapes of Western, Central, and Eastern European countries were shaped. He explained that the central part of Europe experienced three rapid turnovers that strongly influenced the landscape and did not give a chance to create visible patterns that reflect historic development. Firstly, imperial landscapes happened prior to 1918 when the Russian Empire was at its peak, followed by the emergence of national states and the increase of nationalist values. During the second period, post-World War II brought socialist values, scenery, and practices. Examples of those changes that had a direct influence on the agricultural landscape might be the case of Polish private farms that were transformed into state farms (pl. Państwowe Gospodarstwo Rolne). It was formed of socialist land ownership in 1949-1993 that also caused land consolidation. The third phase—the 1990's—brought the return to the West and a rapid decline of agricultural practices. The capitalist economy brought the most rapid changes that nowadays influence the landscape significantly. In the suburban area of Wrocław, it is reflected by huge shopping mall areas (commercial areas) with daily family facilities (cinema, gym, and restaurants), magazines and buildings with logistic function, communication areas (communication knots), industry, and new residential settlements. The fourth phase can be identified after 2004 when Poland joined the European Union [15]. In the period of 2004-2014, the main landscape changes were the loss of agricultural land and the increase of residential areas [16,17]. Dealing with the process of urbanization and industrialization made Poland join the realities of Western Europe countries [18]. Another aspect clearly visible in the public space is commercialization, as Poland had no regulation considering advertisement until the so-called "Landscape Act" [19]. This act was issued as the effect of Poland signing the ELC in 2004. It took over ten years to make the legal changes and, as it is included in the ELC, to start the process of auditing landscapes. Landscape audits will be conducted at the regional level (scale 1:50,000) and will cover the whole country [20]. Although, for a country that did not have a landscape character assessment [6], it was a great step. Land use policy is legally expressed by Local Development Plans at the municipality level. Therefore, this is necessary to recognize and manage landscape at the local level [21,22]. There is a need to understand the gap between central strategies for landscape and management policies on the local level [23]. The topic of landscape management and urban pressure $[24,25]$ as well as the influence of spatial policy on landscape at the municipality level has been recognized in the literature [26-28]. The strong relationship between landscape and land use policy is also related to the river basin management plans and Water Framework Directive [29]. The municipality of Wrocław and some of its suburban municipalities (Siechnice, Czernica, Miękinia, and Oborniki Ślaskie) are located in the basin of the Odra river, which influences the visual and structural character of the landscape and needs to be considered in the Local Development Plans [30-32]. 


\subsection{Research Context and Aim of the Study}

As the result of ratifying the ELC by Poland, the act on 24 April 2015 that amended certain acts in connection with the strengthening of landscape protection tools [19] was adopted. The tool that is used to identify landscape types across the country is a landscape audit. The methodology to identify landscapes [20] is based on Chmielewski et al. [33] called the Typology of Poland's current landscapes, which assumes that landscape typological maps with respect to certain generalization present similar but distributed territorial units repeating themselves in time and space. It divides Polish landscapes into three groups depending on anthropogenic transformation that breaks down into 15 types and 49 sub types based on land cover, landscape structure, and function (Table 1). To identify the borders of different landscape types and sub types, the criteria of "landscape background" is used. Landscape background is understood as a structural element (or group of similar types of structural elements), is highlighted due to its coverage of the dominant surface within the landscape, is common for all the farthest points of the border landscape, or is the background of most of the other elements of the spatial landscape [33].

Table 1. Groups and types of Poland's current landscapes by Chmielewski and others (2015).

\begin{tabular}{|c|c|}
\hline Group & Type \\
\hline \multirow{5}{*}{$\begin{array}{l}\text { A. Natural landscapes of cultural (usually extensive) use, functioning mainly as a result } \\
\text { of natural processes, modified by human activity only in varying degrees }\end{array}$} & 1. Surface water \\
\hline & $\begin{array}{l}\text { 2. Marshy-meadow-mostly } \\
\text { treeless }\end{array}$ \\
\hline & 3. Forest \\
\hline & $\begin{array}{l}\text { 4. Non-forest, masonry, } \\
\text { sandy and rocky }\end{array}$ \\
\hline & $\begin{array}{l}\text { 5. Mountain over forest } \\
\text { border }\end{array}$ \\
\hline \multirow{3}{*}{$\begin{array}{l}\text { B. Natural and cultural landscapes, formed as a result of the joint action of natural } \\
\text { processes and the conscious modification of land cover and spatial structures by man }\end{array}$} & 6. Agricultural \\
\hline & 7. Mosaic \\
\hline & 8. Suburban and residential \\
\hline \multirow{7}{*}{$\begin{array}{l}\text { C. Cultural landscapes, formed as a result of conscious modification of land cover and } \\
\text { spatial structures by man }\end{array}$} & 9. Provincial \\
\hline & 10. Urban \\
\hline & 11. Water-economic \\
\hline & 12. Industrial \\
\hline & 13. Mining \\
\hline & 14. Communication \\
\hline & 15. Ludic \\
\hline
\end{tabular}

So far, research has focused on developing a method for landscape recognition and valuation on regional scale [20]. This method has been recently tested in urban areas [34] and metropolitan regions [35]. The key map of cultural landscapes on the national level was developed by Plit [36], and it is called the "Historical-cultural regionalization of Poland". It adopts a three-level division of the country into regions with different historical backgrounds, represents the incomparability of the landscapes, and represents landscape division maps [9].

The landscape identification process designed for a landscape audit is based on a "top-down" approach. The basis for the delimitation of higher delimitation levels is the division into physicogeographical regions of J. Kondracki [37], and lower levels are the local structure and texture of land cover forms. As a consequence, the starting point is the regional order, hierarchically systematized. The actual division is described by physicogeographical mesoregions, which are too general for landscape classification. The first stage of the landscape identification process is the delimitation of microregions based on the basis of abiotic criteria (including geological and lithological, 
geomorphological, and hypsometric differentiation). Within microregions, landscape types are identified based on land cover forms (landscape structure and texture). The database of topographic objects (scale 1: 10,000) is the main land cover data source suggested for the identification of landscape types by the authors of the landscape audit methodology in Poland [20]. We believe that, at this stage, the automatization process can be applied in order to objectify the process of landscape identification which has a subjective character and is based on expert knowledge.

Landscape recognition and valuation is a time-consuming process that needs to be done by experts (spatial planners and landscape architects). However, it is known that the landscape identification process depends mostly on expert knowledge, and GIS tools can be used only as a support [33]; in this paper, we aim to recognize for which particular landscape types the use of spatial data and an automatic process will be especially useful to improve landscape identification. We design an automatic landscape identification method based on the recommendations for the landscape audit with the use of easily available spatial data that can be used by planners and decision-makers. In the following section, we briefly describe the case study area, the data, and the design of the automatic landscape identification method. The section Results presents the effectiveness of our method and at what stage it can be helpful in the landscape identification process. We compare the results achieved with the use of the landscape identification method designed for a landscape audit and with the use of automatized process. In the section Discussion, the pros and cons of the described method are presented. In the last section, we draw the conclusions about the landscape identification process and on what stage and degree it can became automatic.

\section{Materials and Methods}

The case study area is the municipality of Siechnice located within the suburban area of the city of Wrocław in the Lower Silesia Region, Poland (Figure 1). Dynamic land cover changes and suburbanization pressure make the municipality of Siechnice favorable for investigation. In the urban-rural fringe spatial changes are rapid, and the landscape is changing its character especially since the area consists mainly of agricultural land, which is easier to transform into new functions than, for example, forest or wetlands. The character of housing areas is challenging to assess as the structure of traditional villages is now strongly influenced by the residential architecture.

The municipality of Siechnice $\left(98.57 \mathrm{~km}^{2}\right)$ is located within Wrocław County in Lower Silesian Voivodeship, in southwestern Poland. The seat of the municipality is the town of Siechnice located in the central part. The municipality borders Wrocław from the northwest. The northeastern part of the commune, bounded by the Odra and Oława Rivers, is forested with wetlands and covered by the Natura 2000 sites (PLH020017, PLB020002). The remaining part of the commune is agricultural. Due to the closeness to the city of Wrocław and the presence of a railway station, the municipality is rapidly developing. Many villages have residential character because of the new suburban housing. Before 2009, gmina Siechnice was named Święta Katarzyna, and just in 1997, Siechnice received the city charter. In 2008, a public consultation was conducted to decide on moving the seat of government to the town of Siechnice and on simultaneously changing the name of the municipality. Those two settlements remained closely related and spatially connected, opening the discussion about differences between a provincial and residential landscape character.

The case study area is located within 5 mesoregions [37]: Trzebnickie Hills, Oleśnicka Plain, Wrocławska Valley, Wrocławska Plain, and Strzegomskie Hills. According to the historic-cultural regionalization of Poland, the case study area is located in the northwest district, the region of Lower Silesia and part of Łużyce, and Land of Wrocław (ID7) [36]. 


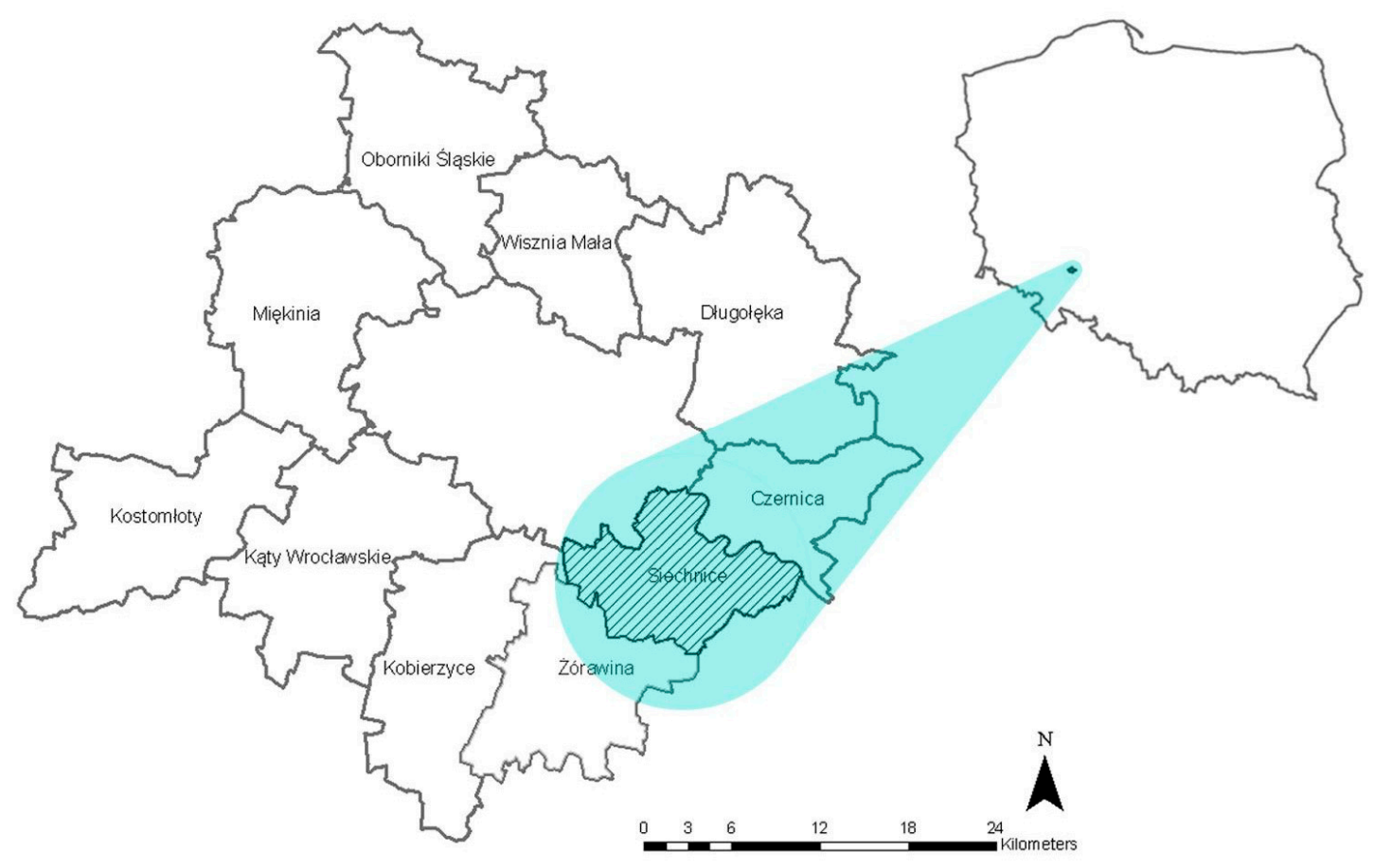

Figure 1. The case study area in the context of the Lower Silesia Region in Poland.

\subsection{Data}

We use a topographic map, an ortophotomap, an administrative position, and a numerical model of the terrain to provide general information about the case study area. The database of topographic objects provides detailed information about the land cover and function. Cadastral data and a map of functional fields are valuable, especially for the identification of agricultural landscapes. A forest map is used to identify the habitats characteristic for forest landscapes. We use the data sources recommended for a landscape audit (Table 2). The spatial data used in this study is free (generally or for the research purposes) and easily accessible to ensure the minimization of the costs associated with acquiring data, thus limiting the process of preparing data for modeling to a minimum and increasing the ease of use. The analysis is performed with the use of GIS software that is also accessible in a free version (e.g., QGIS). In the case study area, the following landscape types are located: marshy-meadow-mostly treeless, forest, agricultural, suburban and residential, and provincial. The types of data used to identify each landscape type and data sources are presented in Table 3.

Provincial and mosaic landscape types are the exceptions and cannot be identified with the use of automatic method. The provincial landscape is characterized by having a central place (usually a market square with a city hall) and different kind of housing (block of flats, single family housing, and multifamily housing). There is a large choice of services and buildings and areas with different functions (e.g., small industry, magazines, education services, physical culture, medical facilities, hotels, church, town hall, and municipality office). The town is connected with other towns and villages with public communication-buses or trains.

The criteria for identification could be the contribution of service buildings in all buildings in the landscape unit as there are more service buildings in town than in villages and suburban residential areas. For this area of consideration, it was the highest score in the case study area (11\%). As there are no small town in this municipality to compare, it is impossible to set the minimum value of service buildings for criterion. There are also no spatial data available about characteristic structural elements, e.g., market square or city hall.

A mosaic type of landscape by definition consists of different land use types and landscape structures. The identification of this landscape type requires further research on the sharing of different land uses in one landscape unit. 
Table 2. Data source for landscape identification (based on Solon et al. 2015).

\begin{tabular}{|c|c|c|c|c|c|}
\hline Data & Scale & Source & Type & $\begin{array}{l}\text { Costs and } \\
\text { Availability }\end{array}$ & $\begin{array}{c}\text { Graphical } \\
\text { Representation }\end{array}$ \\
\hline Topographic map & $1: 25,000$ & Geoportal & raster & $\begin{array}{l}\text { free for research } \\
\text { purposes }\end{array}$ & \\
\hline $\begin{array}{c}\text { Database of } \\
\text { topographic objects }\end{array}$ & $1: 10,000$ & & vector & $\begin{array}{l}\text { free for research } \\
\text { purposes }\end{array}$ & \\
\hline $\begin{array}{l}\text { Database of general } \\
\text { geographic objects }\end{array}$ & $1: 10,000$ & & vector & free download & \\
\hline $\begin{array}{c}\text { Ortofotomap } \\
\text { (pixel size } 0.5-1.0 \mathrm{~m} \text { ) }\end{array}$ & $1: 5000$ & & raster & $\begin{array}{l}\text { free for research } \\
\text { purposes }\end{array}$ & \\
\hline $\begin{array}{l}\text { Administrative } \\
\text { position }\end{array}$ & $1: 5000$ & & vector & free download & \\
\hline $\begin{array}{l}\text { Numerical model of } \\
\text { the terrain } 1-25 \mathrm{~m}\end{array}$ & $1: 50,000$ & Copernicus & vector & free download & \\
\hline $\begin{array}{l}\text { Map of functional } \\
\text { fields }\end{array}$ & $1: 5000$ & & vector & $\begin{array}{l}\text { free for research } \\
\text { purposes }\end{array}$ & \\
\hline Cadastral data & $1: 5000$ & & vector & free download & \\
\hline Forest map & $1: 10,000$ & $\begin{array}{c}\text { Office of Forest Management } \\
\text { and Geodesy }\end{array}$ & vector & free download & \\
\hline
\end{tabular}


Table 3. Data sources for landscape type identification with the use of aggregation.

\begin{tabular}{|c|c|c|c|}
\hline Code & Type & Type of Data & Data Source \\
\hline \multirow[t]{2}{*}{$\mathrm{A} 2$} & \multirow[t]{2}{*}{$\begin{array}{l}\text { Marshy-meadow-mostly } \\
\text { treeless }\end{array}$} & Code C (grassland) from Map of functional fields & $\begin{array}{l}\text { Agency for Restructuring } \\
\text { and Modernization of } \\
\text { Agriculture }\end{array}$ \\
\hline & & $\begin{array}{l}\text { Code OIMK (marsh), OISZ (rashes) from } \\
\text { Database of topographic objects }\end{array}$ & $\begin{array}{l}\text { Central Office of } \\
\text { Geodesy and } \\
\text { Cartography }\end{array}$ \\
\hline $\mathrm{A} 3$ & Forest & Forest map & $\begin{array}{l}\text { Office for forest } \\
\text { management and } \\
\text { geodesy }\end{array}$ \\
\hline B6 & Agricultural & $\begin{array}{l}\text { Code PTTR (grassy vegetation and cultivation on } \\
\text { agricultural land), PTWP (surface water), } \\
\text { PTUT03 (orchard) from Database of topographic } \\
\text { objects }\end{array}$ & $\begin{array}{l}\text { Central Office of } \\
\text { Geodesy and } \\
\text { Cartography }\end{array}$ \\
\hline \multirow[t]{2}{*}{ B8 } & \multirow[t]{2}{*}{ Suburban and residential } & $\begin{array}{l}\text { Code BUBD01-06 (one family housing, two } \\
\text { family housing, three or more family housing, } \\
\text { buildings of collective residence, hotels, } \\
\text { buildings with tourist functions, others), BUBD18 } \\
\text { (rural housing), KUZA (monumental-historic } \\
\text { complex) from Database of topographic objects }\end{array}$ & $\begin{array}{l}\text { Central Office of } \\
\text { Geodesy and } \\
\text { Cartography }\end{array}$ \\
\hline & & Cadastral data & \\
\hline $\mathrm{C} 9$ & Provincial & $\begin{array}{l}\text { Code BUBD01-06 (one family housing, two } \\
\text { family housing, three or more family housing, } \\
\text { buildings of collective residence, hotels, } \\
\text { buildings with tourist functions, others), } \\
\text { BUBD07-17 (services), BUBD19 (religious } \\
\text { function), BUBD20 (monuments) from Database } \\
\text { of topographic objects }\end{array}$ & $\begin{array}{l}\text { Central Office of } \\
\text { Geodesy and } \\
\text { Cartography }\end{array}$ \\
\hline
\end{tabular}

\subsection{Methods}

First, we identify landscape types manually based on the method designed for a landscape audit [33] with the use of spatial data and expert knowledge. We use the results of manual identification as a reference point to design an automatic process with the use of GIS software. Manual identification of landscape types is based on applying information layers and follows the instruction and recommendations for a landscape audit to identify landscape types [20]. With the use of the manual method, the following steps must be applied:

1. Collection of data sources and maps (see Table 2)

2. Identification of landscape types

3. Drawing landscape units

To use this method, the user needs knowledge on how to identify a border between landscape types, what is the size of a landscape type unit, what will be the legal consequence of drawing landscape units, and what is the use of landscape identification for local planning purposes. Those identification criteria are the basics to creating an automatic method.

2.2.1. Aggregation of Data for the Use of Identification of Landscape Types: Marshy-Meadow-Mostly Treeless, Forest, and Agricultural

To design an automatic identification process we develop a different approach for each landscape type: marshy-meadows-mostly treeless, forest, and agricultural. We focus on searching the criteria for characterize landscape types that can be automatically identified. As the minimum area for a landscape unit to be characterize, we accept 20 ha. An area smaller than this cannot create a landscape background itself as it is not perceived by humans as a dominating surface covering in the open field.

A definition that we found helpful in landscape identification is landscape background. For the purpose of transformation, we outlined following criteria: 
1. dominating surface coverage;

2. appearing within the whole landscape unit (touching or creating the borders of the landscape unit).

We translate this definition to aggregate land cover patches of the same category. Data sources are presented in the Table 3. We present the characteristics of each landscape type below. Special attention is given to the suburban and residential landscape type. The procedure to identify this landscape type is explained in Section 2.2.2.

Marshy-Meadow-Mostly Treeless

The landscape background is formed by plant communities of non-forest wet and bog habitats. There may appear surfaces of moist bushes and forests of various sizes. Small areas used for agriculture and the settlement network should be treated as spatial elements of the landscape. This landscape type is usually located near rivers and lakes and in depressions and valleys.

Data about marshy-meadow landscapes is organized in both sources: database of topographic objects and map of functional fields. The database of topographic objects contains information about grassland, and a map of functional fields contains information about marsh and rashes.

Forest

Landscape background consists of forests, temporarily deforested forest land, and forest roads (forest land permanently unwooded-for example, water, buildings, and non-forest land in the forest complex do not fall into the background).

Data about forests is organized by compartments in each forest district. A forest in the municipality of Siechnice is entirely located within the Oława district and was used as an input data set. Input data was clipped to the administrative borders of the municipality of Siechnice. Subareas of forest within the municipality were aggregated with the use of the tool "Aggregate Polygons" with the aggregation distance equal $200 \mathrm{~m}$. It helped to join and generalize forest patches. The final step was deleting polygons with sizes smaller than 20 ha to eliminate small patches that did not conceive the landscape background.

Agricultural

The landscape background is land used currently for agriculture (arable land, meadows, and pastures), in the recent past (fallow land and fallow land), or large-scale flood reservoirs for retention and recreation. The share of other forms of land cover (forests, wasteland, and other areas outside built-up areas) can be very variable. Usually, a village is located in the central part of the field system. In the typical rural area, most of the houses have direct access to the agricultural land. The settlements are located in the crossroads or along the road. The field size is bigger that in the suburban area as the plot has also other functions, not only residential. The services are limited to the basics (e.g., shop, car workshop, household shop, church, and primary school).

Based on the database of topographic objects, we locate the main elements of agricultural landscape: grassy vegetation, cultivation on agricultural land, surface water, and orchards.

\subsubsection{Identification with the Use of Multivariable Analysis of Suburban and Residential Landscape}

In this section, we describe how we identified areas of suburban and residential housing manually using spatial data and expert knowledge. Next, we take an attempt to create a logistic model which learns from manual identification and automatically identifies them with the best accuracy. Identification is made in an ArcGis environment, and a multivariable analysis of identified areas is made in an R environment. The relations discovered in the multivariable analysis we implement back to ArcGis to create a special tool to automatically identify areas. 
To identify suburban and residential landscape types manually, we use a database of topographic objects. This data source gives information about location, size, and type of housing. Housing is located in groups of different sizes and structures that can be identified by an expert as a village, city, or suburban housing settlement. To identify the character of housing, we make an automatic model based on assumptions and knowledge about suburban and residential housing.

As functioning of the landscape and its structure are strongly related, the location of the municipality of Siechnice in the rural-urban fringe is reflected in the structure of housing areas. In many cases, economically driven change in uniform landscape loses its identity. The number of people willing to work in cities and life outside of them is growing. New housing is characterized with small, low buildings preserving their non-city character [38]. Those settlements are also colloquially called "the bedrooms of Wrocław". The research shows that the degree of land-use diversity and landscape fragmentation are positively related to the degree of urbanization, and the strongest relationship reflects changes in residential land-use patterns [39]. The main criteria for suburban areas is contentedness with the big city. A majority of the houses consists of single-family housing located around the road. Suburban housing is characterized by Antrop [38] as small, low buildings with a back garden and a non-city character. Typical suburban housing in our case study area is single-family housing with a garden and a front yard located within the plot between $600 \mathrm{~m}^{2}$ and $2000 \mathrm{~m}^{2}$ [17]. Housing plots are located one next to the other, with no access to agricultural land. New roads are designed parallel and perpendicular to the main road, creating a "block" of new housing. Usually there is no central place within the settlement and the services are strongly limited (e.g., grocery and private kindergarten) as the residents of this area are visiting the big town on a daily basis. The landscape background consists of residential or hotel buildings complexes surrounded by forest; intense and compact rural buildings with a residential function; or historical, large-scale forest-water-agro-settlements (e.g., a palace and park complex).

We identify manually 18 areas of consideration to decide their character: rural or suburban and residential. Those sectors are analyzed in terms of structure with the use of a multivariable analysis to identify sectors with suburban and residential housing. Those sectors are characterized with a big variability of plots in the sector (from 20 to 3000). We use sample analysis [40] to find the proper number of plots in a representative sector. We make over 1000 sample simulations that confirm that the representative number of plots in a sector is 200 according to the input data. This number of plots stabilizes the variance of the area in a sector (Figure 2). The sectors that contain a lower number of plots then 200 cannot be automatically characterized in our case by any of the variables. We took these plots as rural because all sectors without plots under 200 are rural according to expert opinion.

We calculate Shape Index (SI) according to the following formula:

$$
\mathrm{SI}=\mathrm{p} /(4 \times \sqrt{ } \mathrm{a})
$$

where $\mathrm{p}$ is the perimeter of the cadastral plot; a is the area of the cadastral plot; and SI is the Shape Index.

We separate sectors that have more than 200 plots, and according to the character of sectors assigned by experts, we found 2 parameters that can be used for analysis due to their variety (Figure 3 ). Setting the percentage of the area of agricultural buildings in relation to the plot area at $2.6 \%$, we get $75 \%$ of the samples of rural character above that barrier and almost $75 \%$ of the samples of suburban character under $2.6 \%$. The Shape Index equals 1.22 and divides $75 \%$ of the sectors of rural character above and $68 \%$ of the sectors of suburban character under 1.22. It means that if we pick a plot with an SI equal 1.23 , we have a $75 \%$ chance to take a plot with a rural character and only $32 \%$ change to take that with a suburban character.

To create our logistic model of decision about the character of sector, we use 3 predictors. As a first predictor, we check the number of plots in a sector. If it is lower than 200 , we assume that this sector has a rural character. If the number of plots is bigger than 200 , we check the conjunction of the percentage of rural buildings on a plot above $2.6 \%$ or an SI above 1.22 as the second and third predictors. If it is true, we say the plot is rural; otherwise, it is suburban. The third step is to characterize all sectors in 
the municipality. Because of the influence of rural plots, if they appear in a sector with a half frequency of suburban plots, we say that the sector is rural.
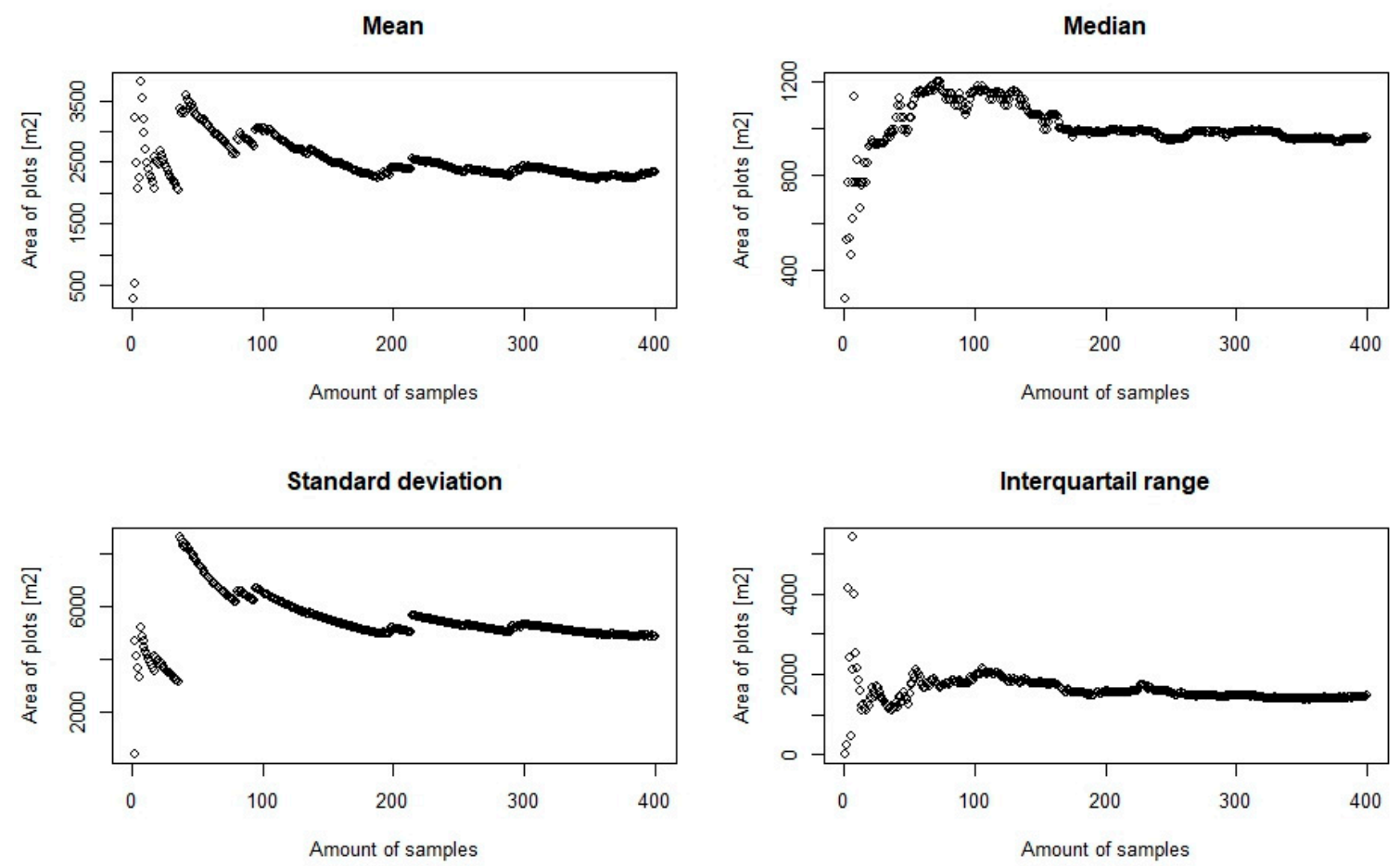

Figure 2. Exemplary distributions of trajectories depending on the sample size in one of the sectors located in the municipality of Siechnice.

Comparing percentege of area of building with agricultural function in relation to the area of the plot in rural and suburban sectors

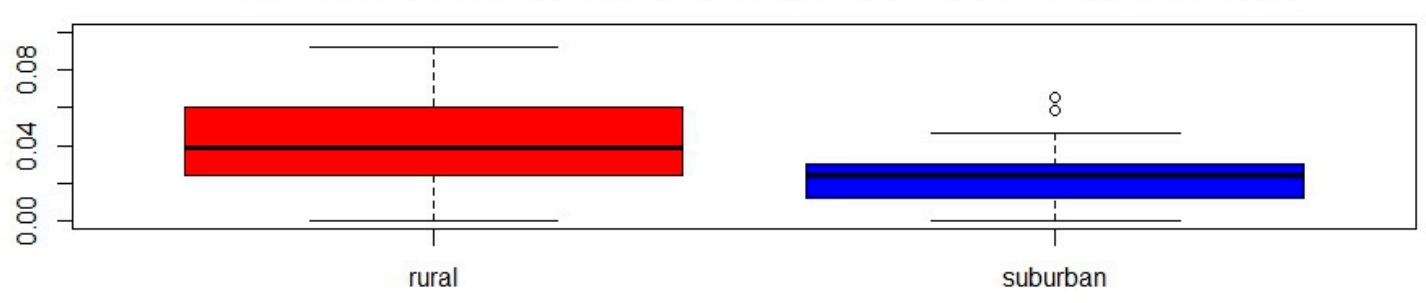

Comparing Shape Index (SI) of housing plot on area of rural and suburban sectors

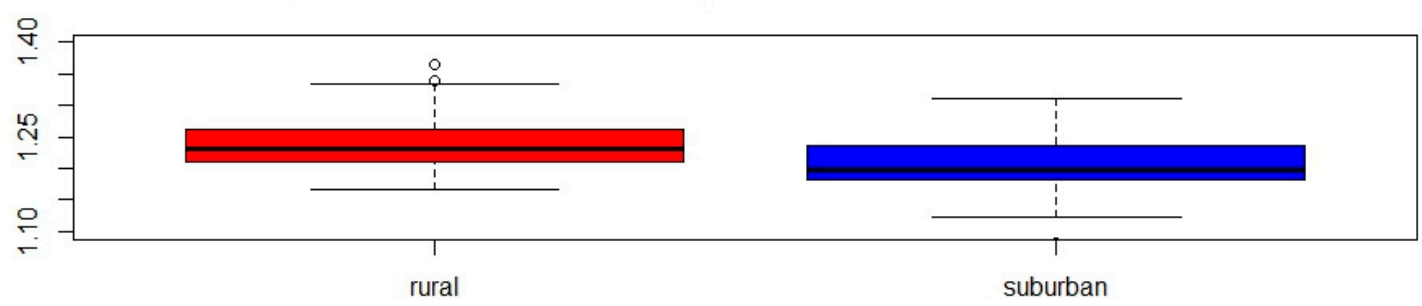

Figure 3. Characteristics of the parameters showing the difference between rural and suburban characters of the housing sector.

\section{Results}

Identification of landscape types with the use of the method for landscape audit shows that the case study area mostly consists of agricultural landscape (73\%) and forest (13\%). However, small (2\%) 
marshy-meadow-mostly treeless is very significant and characteristic in terms of the habitat in this area. Five percent is provincial landscape, which consist of the town of Siechnice and is located in the central part of the municipality; $7 \%$ is suburban and residential landscape which is located in 5 patches and is separated from agricultural land due to dominating suburban housing settlements. With the use of aggregation, we identified two patches of marshy-meadow landscape in the northern and western parts of case study area. A forest landscape patch is located in the eastern part. The picture of agricultural landscape is spread all over case study area. We identified 18 areas of consideration within the municipality of Siechnice (Table 4). After applying a multivariable analysis, we located six units of suburban and residential landscapes in the surrounding of the town of Siechnice and along the border with the city of Wrocław (northwestern part of case study area). The town of Siechnice was also identified as a suburban landscape because, with the use of the model, we were not able to distinguish the town from residential housing area. Structural and visual differences between rural and suburban and residential landscape types are presented on the examples of two areas of consideration in Figure 4.
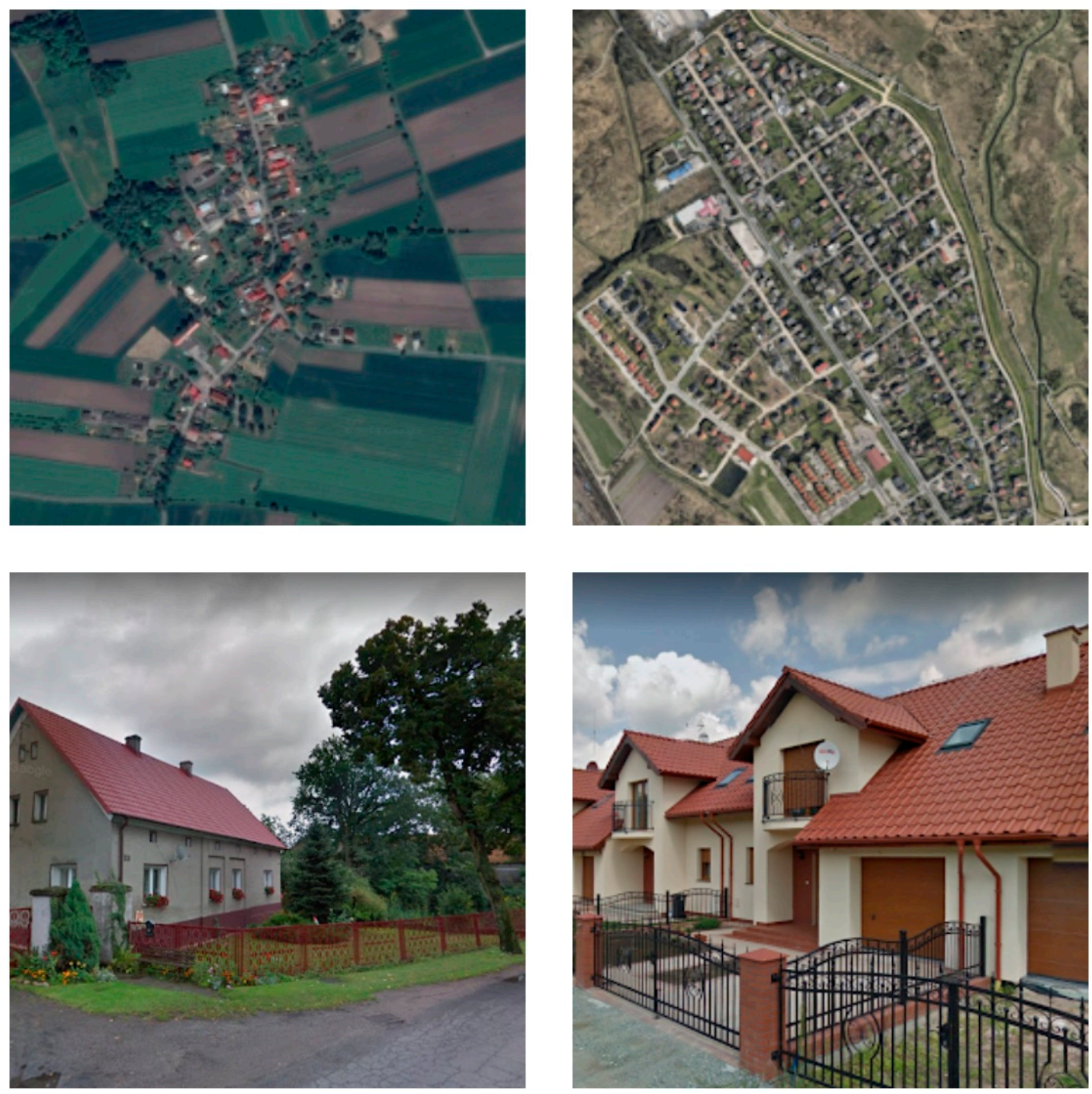

Figure 4. On the left: an example of suburban and residential landscape in the village of Radwanice (area of consideration no 3) located near the main road accessing Wrocław city. On the right: an example of the rural landscape in the village of Sulimów (area of consideration no 9) located in the northern part of the municipality. Source: Google, DigitalGlobe. 
Table 4. Comparison of the results achieved with the use of the landscape audit identification method and a multivariable analysis for the areas of consideration within the municipality of Siechnice.

\begin{tabular}{|c|c|c|c|}
\hline $\begin{array}{l}\text { No of Area of } \\
\text { Consideration }\end{array}$ & Number of Plots & $\begin{array}{l}\text { Type According to Landscape } \\
\text { Audit Identification Method }\end{array}$ & $\begin{array}{l}\text { Type According to the } \\
\text { Multivariable Analysis }\end{array}$ \\
\hline 1 & 53 & rural & rural \\
\hline 2 & 144 & rural & rural \\
\hline 3 & 1285 & rural with residential feature & suburban and residential \\
\hline 4 & 2299 & provincial & suburban and residential \\
\hline 5 & 408 & rural & suburban and residential \\
\hline 6 & 434 & suburban and residential & suburban and residential \\
\hline 7 & 79 & rural & rural \\
\hline 8 & 80 & rural & rural \\
\hline 9 & 132 & rural & rural \\
\hline 10 & 66 & rural & rural \\
\hline 11 & 64 & rural & rural \\
\hline 12 & 114 & rural & rural \\
\hline 13 & 52 & rural & rural \\
\hline 14 & 153 & rural & rural \\
\hline 15 & 97 & rural & rural \\
\hline 16 & 52 & suburban and residential & rural \\
\hline 17 & 424 & suburban and residential & suburban and residentia \\
\hline 18 & 1551 & suburban and residential & suburban and residentia \\
\hline
\end{tabular}

\section{Data Verification}

A comparison of both methods shows that an identification of landscape types with the use of an automatic method is very effective for particular landscape types and not effective for others. It was especially effective in identifying the types of forest, marshy-meadow-mostly treeless, and agricultural landscape and not effective for mosaic and provincial landscapes. Very challenging was the identification of suburban and residential landscapes. Areas identified with the use of the automatic method were $12 \%$ bigger than the area identified with the manual method. The automatic method can be used as a preliminary assessment because it makes the identification of suburban areas much easier for an expert. A comparison of both methods is presented in Figure 5 and Table 5. 


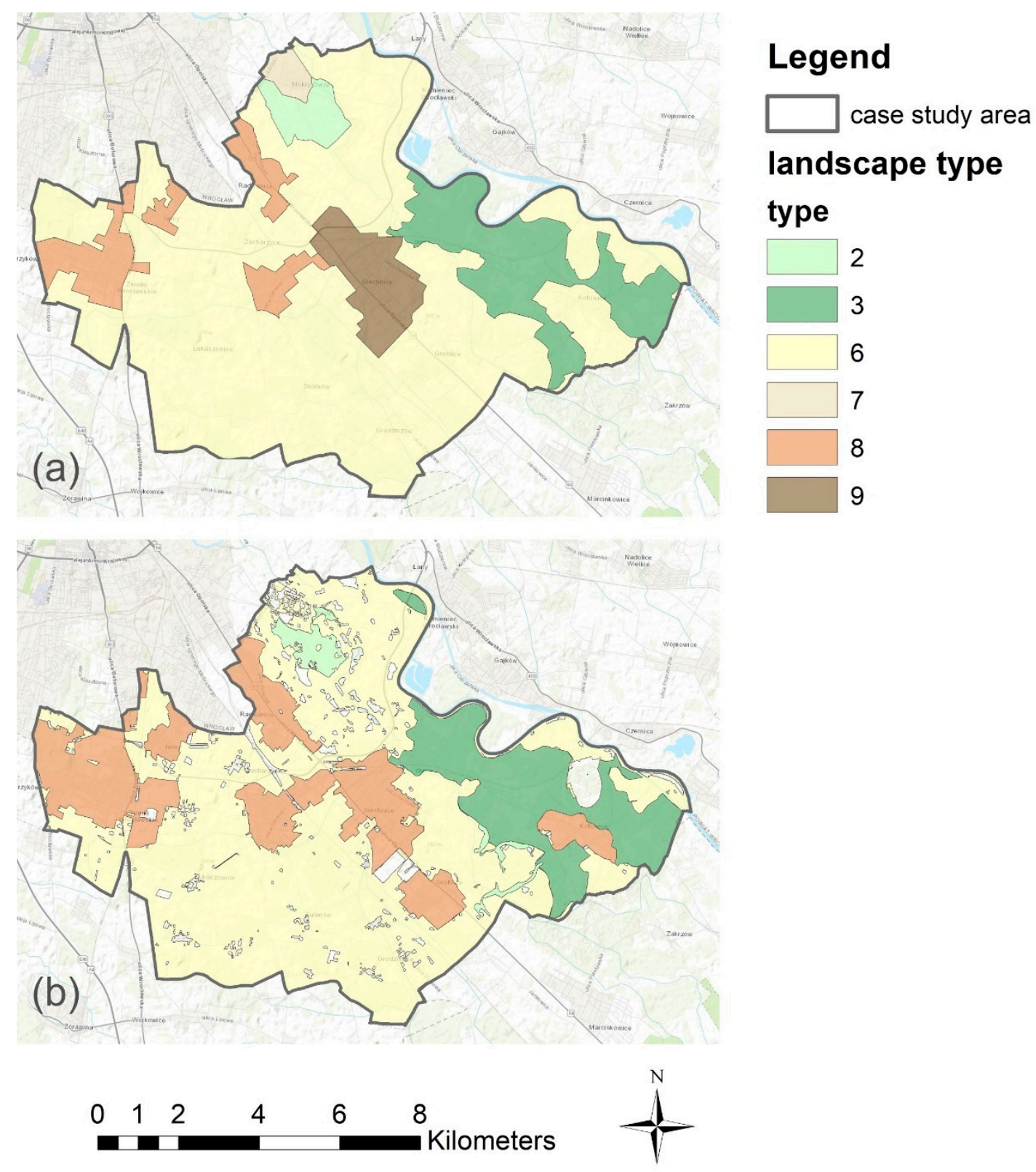

Figure 5. Landscape types in the municipality of Siechnice identified with the use of two approaches: (a) method designed for landscape audit; (b) automatic method presented in this paper. Legend: numbering of landscape types according to typology (Chmielewski i in., 2015): 2-marshy-meadow-mostly treeless; 3-forest; 6-agricultural; 7-mosaic; 8-suburban and residential; 9-provincial. Source: own elaboration. 
Table 5. A comparison of the results of landscape types identification. Source: own elaboration.

\begin{tabular}{cccccccc}
\hline \multirow{2}{*}{ Code } & Type & \multicolumn{2}{c}{ Method for Landscape Audit } & \multicolumn{2}{c}{$\begin{array}{c}\text { Our Approach for Landscape } \\
\text { Identification }\end{array}$} \\
\cline { 3 - 8 } & $\begin{array}{c}\text { Area } \\
\text { (ha) }\end{array}$ & $\begin{array}{c}\text { Number } \\
\text { of Units }\end{array}$ & $\begin{array}{c}\text { \% of Total } \\
\text { Area }\end{array}$ & $\begin{array}{c}\text { Area (ha) } \\
\text { Ant }\end{array}$ & $\begin{array}{c}\text { Number } \\
\text { of Units }\end{array}$ & $\begin{array}{c}\text { of Total } \\
\text { Area }\end{array}$ \\
\hline A2 & $\begin{array}{c}\text { Marshy-meadow-mostly } \\
\text { treeless }\end{array}$ & 232.05 & 1 & 2 & 256.71 & 3 & 3 \\
\hline A3 & Forest & 1241.87 & 1 & 13 & 1285.00 & 2 & 13 \\
\hline B6 & Agricultural & 7188.28 & 5 & 71 & 5895.53 & 3 & 60 \\
\hline B7 & Mosaic & 101,55 & 1 & 1 & 0 & 0 & 0 \\
\hline B8 & Suburban and residential & 802.78 & 5 & 8 & 1992.74 & 7 & 20 \\
\hline C9 & Provincial & 512.08 & 1 & 5 & 0 & 0 & 0 \\
\hline & Not identified & 0 & 0 & 0 & 441.70 & 0 & 4 \\
\hline
\end{tabular}

\section{Discussion}

The identification of landscape units with the use of spatial data and GIS tools has been widely used. Pechanes designed the process of identification of landscape potential based on topological data of soil rating, forest types, and geobiocoene types [41]. In Poland, soil-agricultural maps (scale 1:5000) and forest maps are nationwide databases; however, the absence of geobiocoene data makes this method unavailable.

Another approach to landscape identification data is based on aerial photos. Aerial photos are used to identify landscape changes [15,42-45], and remote sensing is widely used to characterize landscape structure [46,47]. Landscape photos can be easily used to identify landscape elements visually based on pattern and shape. The difficulty in comparing aerial photos from different years comes from the difference in quality and processing over time [48]. This method is also time-consuming. Remote sensing technology has a great potential to deliver detailed information about landscape structures with a high thematic and geometric accuracy $[49,50]$. The choice of classification algorithms affects the result, and the evaluation of several parametric classification algorithms to assess their accuracy on various landscapes is presented by Hubert-Moy et al. [51]. However, this method is limited by the availability of adequate remote sensing data, in terms of spatial and temporal resolution, and digital image analysis techniques [52]. The use of Landsat data is very effective in identifying land cover types, land cover and landscape dynamics [53-55], and Landsat-based data [56]. However landscape types according to Polish typology by Chmielewski et al. [33] not only is based on land cover but also considers landscape structure and function, e.g., metropolitan landscapes include historic urban complexes, business center, residential areas, large shopping and logistics centers and storage facilities, large sports and recreation areas, and large necropolises. Therefore, Landsat data can be applied in a very detailed way (information about land cover type for each pixel), yet it is technically very challenging to distinguish historic urban complex from residential area based only on Landsat data. In this paper, we used easily accessible data that is also free for research purposes to make the landscape identification process easier and to become a base for further landscape and sustainability research, e.g., analyses of landscape changes or analyses of social approach to landscape based on landscape units. The proposed multivariable analysis helps to distinguish villages from new development areas which affect the rural landscape in the peri-urban fringe and, according to the adopted typology, represent different landscape types.

Landscape analysis is also done with the use of land use maps [39,40,57-61] and landscape maps, e.g., of Czech Republic [9] and Turkey [62], also in terms of the assessment of landscape fragmentation [63]. An advantage of this method is the comparability of landscapes and the possibility to apply this method in different places and to receive landscape units. Landscape identification may be 
combined with other methods, e.g., the questionnaire, and may be used to find the link between farming systems and landscape patterns [63]. Landscape models have been recently used for supporting spatial land use decisions [64], environmental modeling [65,66], cultural value assessments [67], and integrated value assessments [68]. The topic of transformation of peri-urban zones and changes in agricultural landscape is being researched in many fields [69-72].

For future research, the method to identify suburban and residential landscape types should be improved. In the urban-rural fringe suburbanization pressure affects the conversion of farmland into new housing areas [17]. The factors that affect land use changes in the peri-urban landscape should be outlined. The structure of new housing areas in the suburban and residential landscapes should be studied to extend the knowledge to identify and distinguish more precisely housing areas with rural characters from that of suburban characters, track landscape changes, and plan suburban areas more effectively.

\section{Conclusions}

In our paper, we attempted to automatize the landscape identification process. Automatizing this process can facilitate landscape identification and support landscape management in the future. Such a process is needed because landscape changes occur very quickly and because periodic landscape identification will serve to identify landscape changes and its driving forces and to determine the directions for future development. This process is vulnerable to characteristics of each landscape type, the types of data used, and the types of geospatial operations.

In this study, we examined the methods of aggregation data and multivariable analysis to identify landscape types. We found out that the method of aggregation of land use data can be helpful in identifying some landscape types and that a multivariable analysis is useful in the process of identification of suburban and residential landscapes.

The results show that our approach can be useful for recognizing landscape types although it cannot replace manual landscape identification fully. Aggregation of data was easy to use in the case of forest and agricultural landscapes. In the case of the forest landscape, using geospatial data and applying criteria were sufficient to identify landscape units. An agricultural landscape is more difficult to identify as the data is very detailed, and according to the typology, rural settlements are also included in the agricultural landscape units. Setting the exact borders of agricultural landscape requires an investigation of the landscape architect. The identification of marshy-meadow-mostly treeless landscape was more difficult because data about grassland, marsh, and rashes come from two different data sources. As the data overlaps, it needs to be decided which dataset to follow in each case.

Suburban and residential landscapes can be identified with the use of a multivariable analysis. Identification with the use of a multivariable analysis characterizes the area of consideration as whole as rural or suburban. With the use of the manual method, one area could be divided into a village (rural character) and suburban settlement nearby. The advantage of this method is that it also shows the potential of the area of consideration to become a suburban settlement. Identification with the use of a multivariable analysis gives us an $89 \%$ efficiency of proper characterization of the sector according to the manual method. We are aware that our method, in which we assign the character of plots to the character of the sector, is a strong generalization. In fact, plots in sectors have diverse characters, but this approach gave important information about each parameter of the housing plots. This gave us the grounds to our logistic model, which works well with reality.

The criteria used to identify suburban landscapes can be different for other areas depending on the landscape character, e.g., size, shape, and number of housing plots and agricultural buildings. This method can be applied to other areas only if the criteria will be adjusted to the landscape character in this particular area. The parameters were determined on the basis of conditions in the Wroclaw region. It should be pointed out that the parameters in other regions may have to be adjusted and that, of course, the size of the sectors influences the quality of the provision, as potentially different functions can exist on an equal footing in large sectors. The exact border of suburban and residential 
landscape units needs to be done manually. The provincial landscape cannot be identified with the use of this method due to lack of information about characteristic landscape elements in available data. However, it can be preliminary identified with the use of criteria used for residential landscape as it has some common features (prevailing housing plots and buildings).

The differences in the area (see Table 5) of suburban and residential landscapes and agricultural landscape identified with the use of both approaches may be caused by rapid landscape changes that are not included in the reference data. The manual method gives the opportunity to notice changes that are not actualized in the data sets.

The presented method is vulnerable to the availability and quality of data. Some of the characteristics could not be transferred to the criteria because of a lack of data, e.g., age or height of the building. The quality of data is also important to classify the building as residential or agricultural (some buildings are classified as agricultural building and do not have this function, e.g., garage) or to classify the location of the building along a main or access road (they are classified as the same class in the available data). However, a big advantage of this method is the choice of data that is easily accessible and mostly free of charge (or free for research purposes) which increases the availability of the method itself.

Author Contributions: Conceptualization I.S. and D.B.; methodology I.S.; software, I.S. and A.G.; validation I.S. and A.G.; formal analysis I.S. and A.G.; investigation I.S. and A.G.; resources I.S.; data curation I.S.; writing - original draft preparation I.S. and A.G; writing — review and editing D.B.; visualization I.S. and A.G.; supervision D.B.; project administration I.S.; funding acquisition I.S.

Funding: The work of Iga Solecka was supported by the Narodowe Centrum Nauki (Grant No. 2016/23/N/HS4/02114).

Acknowledgments: The authors would like to thank Bernd Delakowitz for enabling the contact between research institutions and for providing valuable comments to the first version of this paper.

Conflicts of Interest: The authors declare no conflict of interest.

\section{References}

1. Zonneveld, I.S. Land Ecology: An Introduction to Landscape Ecology as a Base for Land Evaluation, Land Management and Conservation; SPB Academic Publishing: Amsterdam, The Netherlands, 1995.

2. Matías, L.; Mendoza, I.; Zamora, R. Consistent pattern of habitat and species selection by post-dispersal seed predators in a Mediterranean mosaic landscape. Plant Ecol. 2009, 203, 137-147. [CrossRef]

3. Verhoeven, J.T.; Soons, M.B.; Janssen, R.; Omtzigt, N. An Operational Landscape Unit approach for identifying key landscape connections in wetland restoration. J. Appl. Ecol. 2008, 45, 1496-1503. [CrossRef]

4. Bastian, O. Landscape classification in Saxony (Germany)-A tool for holistic regional planning. Landsc. Urban Plan. 2000, 50, 145-155. [CrossRef]

5. Mücher, C.A.; Klijn, J.A.; Wascher, D.M.; Schaminée, J.H. A new European Landscape Classification (LANMAP): A transparent, flexible and user-oriented methodology to distinguish landscapes. Ecol. Indic. 2010, 10, 87-103. [CrossRef]

6. Wascher, D.M. European Landscape Character Areas: Typologies, Cartography and Indicators for the Assessment of Sustainable Landscapes; Technical Report; Landscape Europe: Wageningen, The Netherlands, 2005.

7. Granö, J.G. Eesti Maastikulised Üksused; Mattiesen: Tartu, Estonia, 1922.

8. Europe, C.O. European Landscape Convention; Report and Convention; Council of Europe: Strasbourg, France, 2000.

9. Kolejka, J.; Lipský, Z. Landscapemapping and Typology in the Czech Republic; Problemy Ekologii Krajobrazu, 2014; Volume 20.

10. Miklós, L. Landscape Atlas of the Slovak Republic. In Slovakia: Ministry of Environment of the Slovak Republic; Slovak Environmental Agency Banska Bystrica: Banská Bystrica, Slovak Republic, 2002.

11. Swanwick, C. Landscape character assessment: Guidance for England and Scotland; Making Sense of Place...; Countryside Agency Publications: Cheltenham, UK, 2002.

12. Kondracki, J. Regiony Fizycznogeograficzne Polski; Wydawnictwa Uniwersytetu Warszawskiego: Warszawa, Poland, 1977. 
13. Bogdanowski, J.; Łuczyńska-Bruzda, M.; Novák, Z.; Bańska, M. Architektura krajobrazu; Państwowe Wydawnictwo Naukowe: Warsaw, Poland, 1973.

14. Palang, H.; Printsmann, A.; Gyuró, É.K.; Urbanc, M.; Skowronek, E.; Woloszyn, W. The forgotten rural landscapes of Central and Eastern Europe. Landsc. Ecol. 2006, 21, 347-357. [CrossRef]

15. Krystian, H. Spatial changes in rural areas in Poland during the transition and after accession to the European Union. Rural Areas Rural Space Popul. Soc. Act. Entrep. 2016, 167, 12-27. (In Polish)

16. Krajewski, P.; Solecka, I.; Barbara-Mastalska-Cetera. Landscape change index as a tool for spatial analysis. In IOP Conference Series: Materials Science and Engineering; IOP Publishing: Bristol, UK, 2017; Volume 245.

17. Solecka, I.; Sylla, M.; Świąder, M. Urban Sprawl impact on farmland conversion in suburban area of Wroclaw, Poland. In IOP Conference Series: Materials Science and Engineering; IOP Publishing: Bristol, UK, 2017; Volume 245.

18. Antrop, M. Landscape change and the urbanization process in Europe. Landsc. Urban Plan. 2004, 67, 9-26. [CrossRef]

19. Karpus, K. Legal protection of landscape in Poland in the light of the Act of 24 April 2015 amending certain acts in relation to strengthening landscape protection instruments. J. Lawsitem 2015, 774. [CrossRef]

20. Solon, J.; Chmielewski, T.J.; Myga-Piątek, U.; Kistowski, M. Identyfikacja i ocena krajobrazów Polski-etapy i metody postępowania w toku audytu krajobrazowego w województwach. Probl. Ekol. Kraj. 2015, 40, 55-76.

21. Krajewski, P. Możliwości zastosowania oceny pojemności krajobrazu w planowaniu przestrzennym na obszarach podmiejskich. Archit. Kraj. 2012, 3, 22-29.

22. Krajewski, P. Problemy planistyczne na terenach parków krajobrazowych w sasiedztwie Wrocławia na przykładzie Ślężańskiego Parku Krajobrazowego. Pr. Nauk. Uniw. Ekon. We Wrocławiu 2014, 367, 147-154. [CrossRef]

23. Pinto-Correia, T.; Gustavsson, R.; Pirnat, J. Bridging the gap between centrally defined policies and local decisions-Towards more sensitive and creative rural landscape management. Landsc. Ecol. 2006, 21, 333-346. [CrossRef]

24. Zasada, I. Multifunctional peri-urban agriculture-A review of societal demands and the provision of goods and services by farming. Land Use Policy 2011, 28, 639-648. [CrossRef]

25. Van Eetvelde, V.; Antrop, M. Indicators for assessing changing landscape character of cultural landscapes in Flanders (Belgium). Land Use Policy 2009, 26, 901-910. [CrossRef]

26. Heldak, M.; Raszka, B. Prognosis of the Natural Environment Transformations Resulting from Spatial Planning Solutions. Pol. J. Environ. Stud. 2011, 20, 1513-1518.

27. Hełdak, M.; Raszka, B. Evaluation of the Local Spatial Policy in Poland with Regard to Sustainable Development. Pol. J. Environ. Stud. 2013, 22, 395-402.

28. Hełdak, M.; Raszka, B. Evaluation of the Spatial Policy of a Commune with Regard to Planned Land Use. Pol. J. Environ. Stud. 2013, 22, 125-130.

29. Directive 2000/60/EC of the European Parliament and of the Council Establishing a Framework for the Community Action in the Field of Water Policy. 2000. Available online: http://eur-lex.europa.eu/LexUriServ/ LexUriServ.do?uri=CELEX:32000L0060:en:NOT (accessed on 15 November 2017).

30. Tong, S.T.; Chen, W. Modeling the relationship between land use and surface water quality. J. Environ. Manag. 2002, 66, 377-393. [CrossRef]

31. Hundecha, Y.; Bárdossy, A. Modeling of the effect of land use changes on the runoff generation of a river basin through parameter regionalization of a watershed model. J. Hydrol. 2004, 292, 281-295. [CrossRef]

32. Moss, T. The governance of land use in river basins: Prospects for overcoming problems of institutional interplay with the EU Water Framework Directive. Land Use Policy 2004, 21, 85-94. [CrossRef]

33. Chmielewski, T.J.; Myga-Piątek, U.; Solon, J. Typologia aktualnych krajobrazów Polski, Typology of Poland's current landscapes. Przeglad Geogr. 2015, 87, 377-408. [CrossRef]

34. Pukowiec-Kurda, K.; Myga-Piątek, U. Application of New Methods of Environment Analysis and Assessment in Landscape Audits-Case Studies of Urban Areas Like Częstochowa, Poland. Environ. Eng. 2017, 1-8. [CrossRef]

35. Pukowiec-Kurda, K.; Myga-Piątek, U.; Rahmonov, O. The landscape profile method as a new tool for sustainable urban planning. J. Environ. Plan. Manag. 2019, 1-19. [CrossRef]

36. Plit, J. Przestrzenne zróżnicowanie i cechy charakterystyczne krajobrazów Polski w ujęciu historyczno-kulturowym. Probl. Ekol. Kraj. 2015, 40, 113-134. 
37. Kondracki, J. Geografia Regionalna Polski; Wydawn. Naukowe PWN: Warszawa, Poland, 2000.

38. Antrop, M. Background concepts for integrated landscape analysis. Agric. Ecosyst. Environ. 2000, 77, 17-28. [CrossRef]

39. Weng, Y.C. Spatiotemporal changes of landscape pattern in response to urbanization. Landsc. Urban Plan. 2007, 81, 341-353. [CrossRef]

40. Hsieh, T.; Ma, K.; Chao, A. iNEXT: An R package for rarefaction and extrapolation of species diversity (Hill numbers). Methods Ecol. Evol. 2016, 7, 1451-1456. [CrossRef]

41. Pechanec, V.; Janíková, V.; Brus, J.; Kilianová, H. Typological data in the process of landscape potential identification with using GIS. Morav. Geogr. Rep. 2009, 17, 12-24.

42. Špulerová, J.; Dobrovodská, M.; Lieskovsky, J.; Baca, A.; Halabuk, A.; Kohút, F.; Mojses, M.; Kenderessy, P.; Piscová, V.; Barancok, P.; et al. Inventory and classification of historical structures of the agricultural landscape in Slovakia. Ekológia (Bratislava) 2011, 30, 157-170.

43. Van Eetvelde, V.; Antrop, M. Analyzing structural and functional changes of traditional landscapes two examples from Southern France. Landsc. Urban Plan. 2004, 67, 79-95. [CrossRef]

44. Bender, O.; Boehmer, H.J.; Jens, D.; Schumacher, K.P. Using GIS to analyse long-term cultural landscape change in Southern Germany. Landsc. Urban Plan. 2005, 70, 111-125. [CrossRef]

45. Feranec, J.; Jaffrain, G.; Soukup, T.; Hazeu, G. Determining changes and flows in European landscapes 1990-2000 using CORINE land cover data. Appl. Geogr. 2010, 30, 19-35. [CrossRef]

46. Ihse, M. Swedish agricultural landscapes-Patterns and changes during the last 50 years, studied by aerial photos. Landsc. Urban Plan. 1995, 31, 21-37. [CrossRef]

47. Rawat, J.; Kumar, M. Monitoring land use/cover change using remote sensing and GIS techniques: A case study of Hawalbagh block, district Almora, Uttarakhand, India. Egypt. J. Remote Sens. Space Sci. 2015, 18, 77-84. [CrossRef]

48. Niang, A.; Ozer, A.; Ozer, P. Fifty years of landscape evolution in Southwestern Mauritania by means of aerial photos. J. Arid Environ. 2008, 72, 97-107. [CrossRef]

49. Chu, H.J.; Wang, C.K.; Huang, M.L.; Lee, C.C.; Liu, C.Y.; Lin, C.C. Effect of point density and interpolation of LiDAR-derived high-resolution DEMs on landscape scarp identification. Gisci. Remote Sens. 2014, 51, 731-747. [CrossRef]

50. Friedman, J.; Hastie, T.; Tibshirani, R. Regularization paths for generalized linear models via coordinate descent. J. Stat. Softw. 2010, 33, 1-22. [CrossRef]

51. Hubert-Moy, L.; Cotonnec, A.; Le Du, L.; Chardin, A.; Pérez, P. A comparison of parametric classification procedures of remotely sensed data applied on different landscape units. Remote Sens. Environ. 2001, 75, 174-187. [CrossRef]

52. Herold, M.; Scepan, J.; Clarke, K.C. The use of remote sensing and landscape metrics to describe structures and changes in urban land uses. Environ. Plan. A 2002, 34, 1443-1458. [CrossRef]

53. Hird, J.N.; Castilla, G.; McDermid, G.J.; Bueno, I.T. A simple transformation for visualizing non-seasonal Landscape change from dense time series of satellite data. IEEE J. Sel. Top. Appl. Earth Obs. Remote Sens. 2015, 9, 3372-3383. [CrossRef]

54. Ju, J.; Masek, J.G. The vegetation greenness trend in Canada and US Alaska from 1984-2012 Landsat data. Remote Sens. Environ. 2016, 176,1-16. [CrossRef]

55. Singh, S.K.; Srivastava, P.K.; Szabó, S.; Petropoulos, G.P.; Gupta, M.; Islam, T. Landscape transform and spatial metrics for mapping spatiotemporal land cover dynamics using Earth Observation data-sets. Geocarto Int. 2017, 32, 113-127. [CrossRef]

56. Parent, J.R.; Volin, J.C. Validating landsat-based landscape metrics with fine-grained land cover data. Ecol. Indic. 2016, 60, 668-677. [CrossRef]

57. Deng, J.S.; Wang, K.; Hong, Y.; Qi, J.G. Spatio-temporal dynamics and evolution of land use change and landscape pattern in response to rapid urbanization. Landsc. Urban Plan. 2009, 92, 187-198. [CrossRef]

58. Zaizhi, Z. Landscape changes in a rural area in China. Landsc. Urban Plan. 2000, 47, 33-38. [CrossRef]

59. Kong, F.; Yin, H.; Nakagoshi, N.; Zong, Y. Urban green space network development for biodiversity conservation: Identification based on graph theory and gravity modeling. Landsc. Urban Plan. 2010, 95, 16-27. [CrossRef]

60. Krajewski, P.; Solecka, I.; Mrozik, K. Forest Landscape Change and Preliminary Study on Its Driving Forces in Ślęża Landscape Park (Southwestern Poland) in 1883-2013. Sustainability 2018, 10, 4526. [CrossRef] 
61. Poudevigne, I.; Alard, D. Landscape and agricultural patterns in rural areas: A case study in the Brionne Basin, Normandy, France. J. Environ. Manag. 1997, 50, 335-349. [CrossRef]

62. Uzun, O.; Dilek, F.; Erduran, F.; Accedil, S.; Cetinkaya, G. National and regional landscape classification and mapping of Turkey: Konya closed basin, Suğla Lake and its surrounding area. Int. J. Phys. Sci. 2011, 6, 550-565.

63. Baudry, J.; Thenail, C. Interaction between farming systems, riparian zones, and landscape patterns: A case study in western France. Landsc. Urban Plan. 2004, 67, 121-129. [CrossRef]

64. Meyer, B.C.; Grabaum, R. MULBO: Model framework for multicriteria landscape assessment and optimisation. A support system for spatial land use decisions. Landsc. Res. 2008, 33, 155-179. [CrossRef]

65. Aspinall, R.; Pearson, D. Integrated geographical assessment of environmental condition in water catchments: Linking landscape ecology, environmental modelling and GIS. J. Environ. Manag. 2000, 59, $299-319$. [CrossRef]

66. Liao, J.; Tang, L.; Shao, G.; Su, X.; Chen, D.; Xu, T. Incorporation of extended neighborhood mechanisms and its impact on urban land-use cellular automata simulations. Environ. Model. Softw. 2016, 75, 163-175. [CrossRef]

67. Stephenson, J. The Cultural Values Model: An integrated approach to values in landscapes. Landsc. Urban Plan. 2008, 84, 127-139. [CrossRef]

68. Gómez-Sal, A.; Belmontes, J.A.; Nicolau, J.M. Assessing landscape values: A proposal for a multidimensional conceptual model. Ecol. Model. 2003, 168, 319-341. [CrossRef]

69. Solon, J. Spatial context of urbanization: Landscape pattern and changes between 1950 and 1990 in the Warsaw metropolitan area, Poland. Landsc. Urban Plan. 2009, 93, 250-261. [CrossRef]

70. Solon, J. Anthropogenic disturbance and vegetation diversity in agricultural landscapes. Landsc. Urban Plan. 1995, 31, 171-180. [CrossRef]

71. Yang, Y.; Zhang, S. Historical Arable Land Change in an Eco-Fragile Area: A Case Study in Zhenlai County, Northeastern China. Sustainability 2018, 10, 3940. [CrossRef]

72. Lee, Y.C.; Ahern, J.; Yeh, C.T. Ecosystem services in peri-urban landscapes: The effects of agricultural landscape change on ecosystem services in Taiwan's western coastal plain. Landsc. Urban Plan. 2015, 139, 137-148. [CrossRef] 